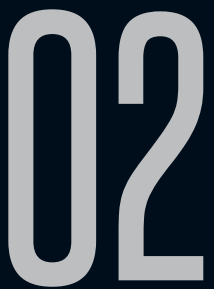

\title{
O EXTRATERRESTRE: ESSE SER MARAVILHOSO DE TODOS OS TEMPOS
}

Luma Maria Braga de Urzedo (UFU) Marisa Martins Gama-Khalil (UFU)

Recebido em 07 dez 2018. Luma Maria Braga de Urzedo é Graduada em Letras Aprovado em 13 fev 2019. Português e Literaturas de Língua Portuguesa pela UFU e Mestranda em Estudos Literários pelo PPGLET - UFU. É Bolsista CAPES e tem como produção mais relevante o artigo intitulado Ficção científica: os maravilhosos E.T.s na literatura latino-americana publicado no livro No território de Mirabilia: estudos sobre o maravilhoso na ficção. É membro do Grupo de Pesquisas em Espacialidades Artísticas (GPEA/ CNPq) e possui interesse nas áreas de Literatura Fantástica e Ficção Científica. Lattes: http://lattes.cnpq. br/3742775719026794. E-mail: lumam.braga@gmail.com

Marisa Martins Gama-Khalil é Doutora em Estudos Literários pela UNESP e Pós-Doutora pela Universidade de Coimbra. É professora da UFU e pesquisadora Produtividade em Pesquisa pelo CNPq. Atua no Programa de Pós-Graduação em Estudos Literários e no PROFLETRAS da UFU. Tem publicações na área da Literatura Fantástica, incluindo ensaios e organização de livros, como Nos labirintos do medo: estudos sobre o medo na ficção; No território de Mirabilia: estudos sobre o maravilhoso na ficção; As literaturas infantil e juvenil ... ainda uma vez. É líder do Grupo de Pesquisas em Espacialidades Artísticas (GPEA/CNPq), atuando nos campos da literatura fantástica, da narratologia 
e do letramento literário. Lattes: http://lattes.cnpq. br/9430138689219946. E-mail: mmgama@gmail.com

Resumo: Personagem maravilhosa recorrente na literatura contemporânea é o extraterrestre; contudo sua irrupção nas obras literárias é muito antiga, remontando o início da era cristã, com Luciano de Samósata. Para tratarmos da configuração do extraterrestre na literatura como um ser maravilhoso de todos os tempos, analisaremos duas obras especialmente, o romance de H. G. Wells A guerra dos mundos e o conto "História da sua vida" de Ted Chiang, ainda que outras obras sejam trazidas ao ensaio, iluminando a representação literária do E.T., como Micrômegas de Voltaire e Uma história verídica de Luciano de Samósata.

Palavras-chave: Literatura fantástica; Ficção científica; Extraterrestre.

Abstract: The extraterrestrial is a recurring marvelous character in contemporary literature; although its irruption in the literary works is very old, related to the beginning of the Christian era, with Lucian of Samosata. To deal with the configuration of the extraterrestrial in literature as a marvelous being of all time, we will analyse two works especially, H.G. Wells's novel The War of the worlds and Ted Chiang's short story, "Story of your life", although other works are brought to the essay, illuminating E.T. literary representation, as Micromegas by Voltaire and A true story of Lucian by Samosata.

Keywords: Fantastic literature; Science fiction; Extraterrestrial.

Diversas são as definições de ficção científica. Algumas possuem um caráter bastante restritivo e a conceituam como um gênero que deve projetar, promover e extrapolar a ciência; outras buscam abranger o máximo de obras possíveis e defendem que a 
ficção científica é mais uma vertente do fantástico. Acreditamos que a ficção científica pode contemplar várias obras que em uma leitura superficial parecem não dialogar. Se projetarmos nosso foco sobre os alienígenas, por exemplo, encontraremos histórias que vão compor facetas discrepantes entre esses seres. Pensemos em dois clássicos do cinema do final dos anos 1970 e início dos anos 1980, Alien': o oitavo passageiro (1979), de Ridley Scott, e E.T. O extraterrestre (1982), de Steven Spielberg.

Ao consultar o site http:imdb.com (Internet Movie Database), que se configura como uma base de dados sobre cinema e séries online, verificamos como os usuários desse site classificam esses filmes de acordo com os gêneros. Alien é definido como horror/scifi, enquanto E.T. é considerado family/sci-fi. O primeiro se passa no espaço em um clima claustrofóbico de perseguição, já o segundo ambienta-se em uma casa cheia de crianças que escondem um ser alienígena amigável dos adultos. Percebemos a partir desses dois exemplos que a ficção científica não se fecha quanto aos seus temas e abordagens, muito menos se engessa em si mesma, mas sim comporta um hibridismo ao se relacionar com outros gêneros, permitindo que um mesmo ser insólito possa aparecer das mais diferentes formas, e, no caso do alienígena, existem muitas possibilidades. Contudo, a maior recorrência na apresentação do alienígena, como nos filmes supracitados, ocorre por meio de dois polos: os alienígenas do bem, aqueles que querem nos ensinar ou apenas estar conosco, e os alienígenas do mal, que buscam tomar ou destruir nosso planeta ou, ainda, que não são receptivos à chegada de terráqueos no espaço.

1 https://www.imdb.com/find?ref_=nv_sr_fn\&q=alien\&s=all 
Além da grande frequência desses tipos antagônicos de extraterrestres existem ainda alguns que possuem uma presença menos maniqueísta, como aquele do filme $O$ dia em que a terra parou (1951), cuja chegada tem a ver com um ultimato (mudem ou morram) e apresenta-nos um ser alienígena que acaba se envolvendo com as mazelas humanas. Contudo, independentemente de suas motivações, os seres extraterrestres são por si só bastante enigmáticos, tanto que fazem parte das nossas narrativas há muito tempo e, ainda hoje, geram inúmeros frutos ficcionais.

O alienígena representa o outro no sentido mais extremo possível: não compartilha de nossa cultura, não possui a mesma composição biológica que a nossa e vem de um lugar longínquo, desconhecido e inexplorado. Além disso, o alienígena ocupa uma posição bastante ambígua entre a crença e a imaginação, como lembra Donald R. Burleson, em seu tópico sobre alienígenas, presente em Icons of horror and the supernatural: an encyclopedia of our worst nightmares:

O ícone alienígena na literatura e no filme difere, em seu impacto sobre a psique humana, de outros ícones do horror e do sobrenatural como o vampiro, o lobisomem, o carniçal e o zumbi. Praticamente ninguém afirma ter tido qualquer experiência, indireta ou não, com vampiros ou zumbis, mas muitas pessoas (mesmo que não tenham tido essas experiências diretamente) pelo menos têm um amigo ou um parente que afirma ter visto algo realmente anômalo nos céus.

Assim, o ícone alienígena é aquele que, pelo menos por boato, desfrutou de alguma exposição na experiência humana, ao contrário, digamos, dos 
lobisomens. Se um alienígena é uma entidade que a tia Claire ou o dentista pode ter visto, ou cuja nave espacial, de qualquer modo, essas pessoas possam ter vislumbrado, então o alienígena entra no reino crepuscular do talvez fictício, talvez não inteiramente fictício. É essa ambiguidade, essa dificuldade na categorização, em parte, que empresta ao ícone seu interesse pelos leitores e pelos patrocinadores do cinema. (BURLESON, 2007, p.2 - tradução nossa) ${ }^{2}$

É necessário contemporizarmos a posição de Burleson, porque sua perspectiva é de um sujeito cuja cultura é estadunidense, onde não se tem com frequência manifestações de contatos com lobisomens, mas sim com alienígenas. Todavia, não se pode dizer o mesmo de algumas localidades brasileiras, nas quais há pessoas que revelam uma suposta experiência com lobisomens. Trata-se, portanto, de uma questão de ordem regional e cultural. Entendemos que o lobisomem (assim como o boto também, por exemplo) vinculase àquilo que Carpentier (2009) denominou real maravilhoso, que é caracterizado como uma manifestação do maravilhoso vinculada à realidade de uma cultura específica e por esse motivo associase a uma crença. No caso do alienígena, compreendemos que a 2 [...] the alien icon in literature and film differs, in its impact upon the human psyche, from such other icons of horror and the supernatural as the vampire, the werewolf, the ghoul, and the zombie. Practically no one claims to have had any experience, indirect or otherwise, with vampires or zombies, but many people (even if they have not had such experiences themselves directly) at least have a friend or a relative who claims to have seen something truly anomalous in the skies.

Thus the alien icon isone that, at least by rumor, has enjoyed some exposure in human experience, unlike, say, werewolves. If an alien is an entity that one's Aunt Clara or one's dentist may conceivably have seen, or whose spacecraft at any rate such people may have glimpsed, then the alien enters that twilight realm of the perhaps fictitious, perhaps not entirely fictitious being. It is this ambiguity, this dificulty in categorizability, in part, that lends the icon its interest for readers and for patrons of film. . (Icons of horror and the supernatural: an encyclopedia of our worst nightmares/edited by S.T. Joshi./The Alien: Donald R. Burleson, 2007, p.2) 
abrangência da suposta experiência (contato) é mais universal, uma vez que há relatos de encontros com alienígenas em todas as partes do mundo.

Por ser esse ser de tamanha complexidade e universalidade, o extraterrestre funciona como um novum, que nos confunde e nos instiga. A partir da explicação dada por Adam Roberts (2018) acerca do conceito de novum de Darko Suvin, é possível compreender melhor como o extraterrestre se configura como um ser ficcional tão caro à ficção científica:

dispositivo, artefato ou premissa ficcionais que põem em foco a diferença entre o mundo que o leitor habita e o mundo ficcional do texto de FC. Um novum pode ser algo material, como uma espaçonave, uma máquina do tempo ou um dispositivo de comunicação mais-rápido-que-a-luz; ou pode ser algo conceitual, como uma nova versão de gênero ou consciência. (ROBERTS, 2018, p.37)

O alienígena funciona como novum na medida em que nos retira de nosso mundo empírico e nos transporta para o outro metaempírico. Optamos pelo termo metaempírico ao invés de sobrenatural, pois, como Filipe Furtado explica em sua definição de modo fantástico presente no e-dicionário de termos literários:

Diversas razões apontam as vantagens operativas do conceito de metaempírico face ao de sobrenatural na abordagem do modo fantástico. Desde logo, o primeiro abrange uma gama bastante mais ampla de figuras e situações. Depois, permite inferir o teor relativo e contingente das noções que qualifica e da forma como estas têm sido encaradas através da história, assim evidenciando a sua estreita dependência da 
sucessão de factores sociais e culturais. Por outro lado, embora a expressão deixe depreender que, pelo menos na sua grande maioria, essas manifestações são indetectáveis e incognoscíveis, não exclui necessariamente a hipótese de algumas delas virem a tornar-se objecto de conhecimento em épocas subsequentes. Daí que muitas personagens e acontecimentos insólitos correntes em narrativas de ficção científica (alienígenas, mundos paralelos, viagens interestelares ou no tempo, etc.), situando-se embora para lá do âmbito mais restrito do sobrenatural, sejam, com este, inteiramente englobáveis no conceito mais lato de metaempírico. Portanto, as narrativas de quase todos os tempos em que elementos a ele circunscritos assumem uma função central no desenvolvimento da intriga constituem (desde a epopeia de Gilgamesh às modernas histórias fantásticas) o que se poderá denominar "ficção do metaempírico", afinal outra designação possível do modo fantástico. (FURTADO, 2018)

Compreender a ficção científica como uma ficção do metaempírico abrange o seu âmbito racionalizante, pois, diferente das fadas, vampiros ou duendes, há um aspecto cognitivo que envolve a aparição do E.T., quer dizer, no caso desse ser metaempírico existem discursos científicos que circunscrevem a possibilidade de sua existência, como o discurso da ufologia e o da cosmologia. Não existem provas concretas da existência de E.T.S, mas existem métodos e estudiosos que investigam essa possibilidade, o que já é suficiente para que ficcionistas criem. Para Suvin (1988), a ficção científica é:

Um gênero literário ou construto verbal cujas condições necessárias e suficientes são a presença 
e interação de distanciamento e cognição, e cujo dispositivo principal é uma moldura imaginativa alternativa ao ambiente empírico do autor. (1988, p.37)

Além disso, o alienígena corresponde a um novum diferente do robô, outra figura muito famosa nas histórias de ficção científica. Diferem-se especialmente pelo caráter projetivo do robô já dotado de inteligência artificial (os robôs já existem em nosso cotidiano, mas ainda não chegaram ao patamar que a ficção científica descreve, de seres autônomos e inteligentes), eles talvez possam existir, mas os alienígenas talvez já existam. Esses robôs aparecem exclusivamente em narrativas futuristas, enquanto os alienígenas podem aparecer em narrativas de qualquer temporalidade, sendo um perigo iminente. Acreditamos que, nesse sentido, o extraterrestre corresponde a um dos grandes ícones da ficção científica, tendo grande influência na consolidação do gênero no gosto popular.

O cinema, o rádio ${ }^{3}$, as séries, as revistas em quadrinhos e os documentários "talvez verdadeiros/talvez fictícios", deram uma especial projeção ao extraterrestre a partir do século $X X$, entretanto a obra que irá funcionar como um marco para as histórias de extraterrestres foi escrita um pouco antes desse "boom" da ficção científica, surge no século XIX, mais precisamente em 1898, o famoso romance de H.G. Wells: A guerra dos mundos.

Em A guerra dos mundos, o embate com o alienígena é levado ao extremo. Até então havia uma predominância da imagem do alienígena amigo, observador, como em Micrômegas (1732),

3 Lembremo-nos da leitura dramatizada do cineasta Orson Welles de A guerra dos mundos, em 1938, às vésperas do Halloween, em uma rádio estadunidense, desencadeadora de pânico na população que acreditou que aquela era, na verdade, uma transmissão ao vivo da chegada de naves espaciais em nosso planeta. 
de Voltaire, ou como um conhecido exótico em uma voyage extraordinaire, como em Uma história verídica, de Luciano de Samósata (II.d.C). O romance de Wells irá influenciar e inspirar na criação de diversas obras sobre invasões alienígenas, como lembra Brian Aldiss no prefácio de A guerra dos mundos (2016, p.30):

É a pedra fundamental de todas as histórias sobre invasões alienígenas impressas ou filmadas. Seguindo o exemplo de Wells, surgiram muitas outras histórias em que o mundo, ou pelo menos a Inglaterra, é devastado. Entre elas estão $A$ nuvem da morte, de Conan Doyle, The Day of the Triffids [O dia das trifides], de John Wyndham, The Death of Grass [A morte do pasto], de John Christopher, The Wind from Nowhere [O vento de lugar nenhum], de J.G.Ballard, O macaco e a essência, de Aldous Huxler, e Herdeiros da Terra, de minha autoria.

Wells cria um novo paradigma para as histórias com seres extraterrestres ao descrever a chegada de marcianos prontos para invadir nosso planeta. Nas quase 300 páginas do romance, temos um narrador que descreve detalhadamente a mudança de sua rotina depois da queda de cilindros repletos de marcianos e tecnologia marciana de guerra. Por essa breve sinopse é possível que o leitor se questione se essa não é só mais uma narrativa de guerra, repleta de clichês, mais um produto da literatura de massa. Infelizmente, é comum o julgamento anterior à leitura dos textos de ficção científica.

Devido a uma dificuldade de distinguir ciência e tecnologia ${ }^{4}$ por parte da crítica e dos leitores, promove-se uma generalização 4 Comumente acredita-se que a tecnologia é derivada da ciência (e nesse sentido acabase excluindo muitas ficções científicas que não se relacionam com as ciências exatas ou artefatos tecnológicos), mas como bem lembra Adam Roberts "(...) a ciência se torna uma moldura filosófica idealista (...) A tecnologia, por outro lado, é o discurso de ferramentas e máquinas, sendo as ferramentas extensões do trabalhador humano [...] e as máquinas, dispositivos que se mantêm a parte do trabalhador humano" (2018, p.49). 
dos textos de ficção científica que resulta em dois preconceitos. O primeiro é o preconceito corrente nos meios acadêmicos e do público dito intelectual pela crença de que a ficção cientifica trata apenas de questões tecnológicas, abandonando questões existenciais e legando ao esquecimento a composição estética. O segundo é o preconceito interior ao gênero, em função de fãs e escritores enxergarem a ficção científica sob essa única perspectiva, considerando as obras não tecnológicas menores ou pseudocientíficas.

Em A guerra dos mundos temos tanto os discursos científicos, mais conceituais, quanto os discursos das máquinas, girando em torno de uma discussão essencialmente humana. Nesse sentindo a obra de Wells também representa um marco para o gênero, já que ela bifurca para ramos muito populares da ficção científica do século seguinte, o especulativo e social/reflexivo.

Seu sentido especulativo que reflete sobre a chegada de alienígenas, seu poderio e nossas possíveis formas de contraataque chamam atenção em uma leitura superficial da obra que acaba servindo como influência para muitas histórias de revistas pulp no século XX e para o cinema hollywoodiano do passado e da contemporaneidade. Esse sentido corresponde ao mais popular, mas ao mesmo tempo mais marginalizado nos meios intelectuais, isso porque Wells foi extremamente original no momento em que escreveu essa obra, que não se tratava meramente de uma discussão especulativa. Contudo, seu modelo foi repetido de forma superficial inúmeras vezes, até se tornar um clichê dentro do gênero. Esse modelo ignora o pessimismo que perpassa a guerra de Wells, dando lugar a histórias nacionalistas 
(especialmente estadunidenses) de bravos soldados humanos que combatem de igual para igual seres alienígenas, como é o caso do filme Independence Day (1996).

A nós interessa principalmente sua segunda contribuição, no aspecto social/reflexivo da ficção científica, especialmente aquela com seres extraterrestres. O narrador de $A$ guerra dos mundos ressalta desde o início a postura de indiferença e soberba do homem, que ignorava a possibilidade de vida em outros planetas até a chegada dos marcianos naquele dia fatídico.

No primeiro momento da narrativa apenas um cilindro foi lançado à Terra e um pequeno grupo de curiosos, que incluía o narrador do romance, cerca esse objeto, até que ele se abre, revelando um alienígena com armamento ultra-avançado que extermina todos ao seu redor. O narrador escapa por sorte e a partir daí parte desesperado, pronto para fugir, mas depara com uma cidade que permanece indiferente aos eventos por ele vividos; os jornais que pouco noticiam sobre a chegada e a população subestima a capacidade destrutiva dos marcianos, já que aquele parecia não conseguir se movimentar com agilidade no planeta Terra. Mais tarde descobre-se que esses seres extraterrenos trouxeram consigo máquinas gigantescas capazes de transportá-los, protegêlos e ainda atacar os humanos com armas de desintegração e calor.

A derrocada humana se dá a partir daí. Os marcianos chegaram com o único objetivo de tomar a Terra para si e essa atitude pode parecer assustadora e maldosa, mas o narrador nos lembra de que nós, humanos, fizemos isso inúmeras vezes em nossa história: 
própria espécie impôs não só a animais, como os extintos bisões e dodôs, mas a suas próprias raças menores. Os tasmanianos, apesar da aparência humana, foram inteiramente dizimados numa guerra de extermínio promovida por imigrantes europeus no espaço de cinquenta anos. Será que somos realmente apóstolos da tolerância para nos queixarmos, quando os marcianos nos combateram com a mesma mentalidade? (WELLS, 2016, p.47-48)

Povos que se consideravam superiores a outros sempre promoveram o extermínio em nosso planeta, foi assim em nossa América também. A Guerra dos mundos nos lembra disso e mostra que, talvez, os motivos dos marcianos fossem mais nobres do que aqueles que levaram nossos ancestrais à exploração de outras terras. Na história, o planeta Marte resfriou e seus habitantes precisavam encontrar um novo local para manter sua espécie viva, a Terra foi escolhida porque era o local mais próximo.

É possível perceber que Wells enxergava o processo de degradação do planeta como natural, visto que em sua história considera que Marte está ruindo por ser um planeta mais antigo que o nosso e não por ter tido seus recursos mais explorados. É normal que discussões acerca do meio ambiente não fossem proeminentes no final do século XIX, momento em que a industrialização começava a ganhar força, mas se lido hoje o romance de Wells pode nos fazer refletir muito acerca de tais questões. Esses marcianos não poderiam representar a nós mesmos daqui a alguns séculos, procurando por um novo lar, quando um possível colapso ambiental do planeta ocorrer?

Como dito, a obra constantemente evidencia uma postura egocêntrica e arrogante da humanidade, que inicialmente subestima 
a chegada dos marcianos e só após se ver imersa no caos percebe que não passa de mais uma dentre todas as espécies do planeta que pode perder espaço, como todas as outras. O alienígena vem à Terra para tomar o topo da cadeia alimentar dos humanos e seus hábitos alimentares são vistos mais uma vez com horror, porém esse horror novamente é relativizado:

Não consigo forçar-me a descrever o que não suportava sequer assistir. Digamos apenas que o sangue obtido de um animal ainda vivo, na maioria dos casos um ser humano, era transferido diretamente, por meio de uma pipeta, no canal receptor.

Por mais que essa ideia seja terrivelmente repulsiva para nós, devemos ter em mente como nossos hábitos carnívoros pareceriam repugnantes a um coelho inteligente. (WELLS, 2016, p.220)

A monstruosidade do alienígena para a humanidade é a mesma que os animais de nosso planeta possivelmente apontariam em nós se pudessem se expressar verbalmente. A indiferença dos marcianos é a mesma que a nossa: "Mas a máquina marciana não deu mais importância às pessoas, que corriam de um lado para outro, do que um homem daria depois de chutar um formigueiro, ao desespero das formigas" (WELLS, 2016, p.135). Os marcianos servem como espelho do domínio desenfreado e do egoísmo humano.

O antagonismo preconizado no título ironiza a relação que se tornará de submissão, pois os humanos mostram-se incapazes de travar uma guerra contra os marcianos e passam apenas a fugir, a guerra acontece, de fato, no mundo microscópico, são as pequenas bactérias terrestres que conseguem vencer ao final: 
Mas não há bactérias em Marte e, assim que os invasores chegaram, assim que começaram a beber e a comer, nossos microscópicos aliados começaram a preparar sua queda. Enquanto eu os observava, eles já estavam irremediavelmente condenados, morrendo e apodrecendo mesmo enquanto se moviam de um lugar para o outro. Era inevitável. (WELLS, 2016, p.283)

Os marcianos eram superiores aos humanos em tudo, exceto em sua capacidade de adaptação às adversidades microscópicas da Terra, e por isso sucumbiram ao final da narrativa. A guerra se mostrou injusta tanto para os humanos, que estavam muito atrasados em relação à tecnologia alienígena, quanto para os marcianos, que enfrentavam, na verdade, adversários invisíveis.

Questões relativas ao controle, à arrogância e à impotência perpassam toda a obra sutilmente, fazendo com que o extraterrestre assuma, então, feições bastante complexas, para além daquela já descrita por nós anteriormente. É nesse sentido que o aspecto social/reflexivo tem maior impacto do que o especulativo. Esses aspectos da obra serão essenciais para se pensar no lugar da ficção científica entre os outros estilos de narrativas de maior prestígio no campo literário. A obra de Wells, ao discutir o humano e não apenas deslumbrar os mais aficionados em tecnologias e geringonças futuristas, serve de inspiração para grandes autores e mostra, ainda, que a generalização e o preconceito pelos textos de ficção científica são infundados.

Mary Shelley, em Frankenstein, discute sobre a possibilidade criadora da ciência, se em algum momento seria possível que o homem se igualasse a Deus, enquanto Wells reflete sobre 
a capacidade destrutiva do desenvolvimento tecnológico, ao estabelecer constantes comparações entre os marcianos, maléficos e invasores, com as ações cotidianas do ser humano. Ambos criaram paradigmas do que a ficção científica viria a ser e seus olhares pessimistas contribuíram expressivamente para que a discussão acerca da sociedade e a reflexão sobre as ações humanas estivessem no cerne do gênero.

O monstro de Dr. Frankenstein serve de inspiração especialmente para as histórias com robôs, androides e super-humanos que se voltam contra seus criadores, enquanto a imagem do E.T. que está pronto para nos exterminar motiva não apenas as obras com seres extraterrestres, mas também aquelas de futuros apocalípticos em que há a devastação de cidades e civilizações, seja por meio de epidemias, ataques de robôs ou problemas ambientais. Todas essas obras que colocam a impotência humana em jogo bebem, de certo modo, da fonte de Wells.

A obra de Wells, juntamente com a de Jules Verne e MaryShelley, representa a vanguarda da ficção científica enquanto uma escritura sistematizada. Antes, muitas obras, em algum nível, discutiam temas e apresentavam personagens que se tornariam clássicos na ficção científica, mas ainda não tinham seu foco nesses seres e temas. Além disso, suas histórias com alienígenas serviram de inspiração na origem do cinema, o primeiro filme de ficção científica Le voyage dans la Lune (1902), que narra a história de astrônomos que viajam até a lua e são capturados por selenitas, é uma adaptação livre do romance de Wells Os primeiros homens da Lua (1901) e do de Verne Da terra à lua (1865). Dentre os vários temas da ficção científica, o primeiro a ser escolhido para ser filmado foi o dos extraterrestres. 
Esse intenso interesse pelos alienígenas, que levou a obra de Wells a conquistar tanto sucesso, a ser até mesmo adaptada para o cinema (que no início do século $X X$ mais parecia um dispositivo de ficção científica do que uma realidade imaginável), é mais antigo do que a própria Cosmologia. Costuma-se pensar que nosso olhar só se lançou para o espaço a partir das descobertas de Copérnico e Galileu, entretanto, mesmo quando acreditava-se que a Terra era o centro do universo, com base nas considerações de Aristóteles e Ptolomeu, que falavam sobre várias esferas, questões de elementos da natureza e elementos misteriosos, os extraterrestres já instigavam a imaginação de escritores. Um grande exemplo é a obra do escritor grego Luciano de Samósata, escrita no século II, intitulada Uma história verídica.

Na história de Luciano, ele e vários homens fazem uma expedição de navio e, levados por uma forte ventania, chegam à Lua que se encontra em guerra com o Sol. Ele e seus tripulantes ajudam a resolver essa briga e retornam ao planeta Terra, fazendo antes uma breve visita ao planeta Vênus que estava sendo colonizado. O narrador descreve os habitantes da lua, seres bizarros e com hábitos peculiares:

Antes de mais, o facto de eles não nascerem de mulheres, mas de seres machos. Na verdade, casam homens com homens, e não conhecem absolutamente nenhum nome de mulher. Até aos vinte e cinco anos, cada um casa fazendo de mulher, e dessa idade em diante faz de marido. E engravidam, não pelo ventre, mas pela barriga das pernas. [...]

Entre eles, é considerado belo quem é calvo ou desprovido completamente de cabelos, ao passo 
que detestam os cabeludos. [...] Além disso, os Selenitas têm barba, a qual cresce um pouco acima dos joelhos, mas não têm unhas nos pés, já que todos são monodáctilos. Acima das nádegas nasceIhes uma grande couve, como se fosse uma cauda, a qual está sempre viçosa e não se quebra se a pessoa cai de costas. [...]

No que respeita aos olhos, hesito em dizer como são, não vá alguém cuidar que minto, tal é o incrível da história. Apesar de tudo, porém, vou contar: têm olhos desenroscáveis, de modo que qualquer um pode tirar os seus e guardá-los, até voltar a precisar de ver; então coloca-os par ver. (s/d, p.37-39)

A descrição nada convencional de Luciano e seu estilo de escrita repleto de ironia são interpretados por Roberts (2018) como uma anti-ficção científica: "Seria mais exato considerar Luciano antes como anti-FC que como proto-FC; mas anti-FC envolve, ainda assim, um compromisso com os termos da FC." (2018, p.76). Acreditamos que a obra de Luciano deve ser pensada como uma das originárias da ficção científica, porque mesmo ironizando a ciência e as crenças de seu tempo, partiu delas para compor sua obra. E mesmo que a passagem pela Lua seja apenas uma das várias aventuras de sua personagem/ narrador (que é ele mesmo), sua obra é de grande importância por mostrar a nós, leitores contemporâneos, que os extraterrestres sempre perpassaram nossa imaginação, independentemente da concepção de Cosmo ou do conhecimento dele.

Sem dúvida de que quanto mais complexa se tornaram nossas ciências os extraterrestres passaram a assumir formas e motivações igualmente mais complexas. Em Uma história verídica os selenitas se parecem com os humanos, têm membros, tronco e cabeça, mas 
com muitas peculiaridades, como já mostramos, e seus modos se assemelham aos dos humanos, eles comem, bebem, dormem, se reproduzem e morrem, mas também de maneira mais bizarra.

A viagem de Luciano para a Lua não é uma viagem tão diferente de uma para um continente distante e inexplorado ou para uma ilha mítica, nela os alienígenas estão em pé de igualdade com outros seres maravilhosos, como árvores com forma feminina que agarram homens na floresta ou pessoas que vivem há anos no estômago de uma baleia. Isso porque a ciência que inspirou o autor grego foi aquela em que a religião grega e as discussões de filósofos, físicos, matemáticos coexistiam e se imbricavam.

Já na obra de Wells, enxergamos uma grande influência das teorias de Charles Darwin, acerca da seleção natural das espécies, teorias que estavam em seu auge, tanto em $A$ guerra dos mundos (1898), quanto em seus primeiros romances, $A$ máquina do tempo (1895) e A Ilha do Dr. Moreau (1896). Na contemporaneidade a influência do darwinismo ainda é forte na composição de textos de ficção científica, tanto que as obras de Wells e de outros autores, como George Orwell e sua Revolução dos Bichos (1945), ainda é bastante lida e estudada. Contudo, questões sobre o tempo e espaço ganham cada vez mais espaço e percebemos que a física quântica, a astrofísica e outras ciências que surgem a partir do século XX influenciam na composição da ficção científica como um todo e que contribuem para uma complexibilização do alienígena dos últimos tempos.

Na chamada Trilogia do Comando Sul, escrita por Jeff Vandermeer, composta por três livros lançados em 2014: Aniquilação, Autoridade e Aceitação, os seres alienígenas não 
possuem uma forma, manifestam-se apenas por meio de uma fronteira invisível que modifica todo o meio ambiente que cerca e as pessoas que lá ousam entrar. Questões de geografia e biologia irão perpassar toda obra, mas podemos destacar também o papel da psicologia nesses romances.

Outra história contemporânea de seres extraterrestres também se aventura por discussões científicas menos convencionais é o conto "História de sua vida", do estadunidense Ted Chiang, que discute principalmente questões de Linguística. Na narrativa, dois cientistas são chamados pelo Coronel Weber, líder do Exército dos Estados Unidos da América, para estudarem os alienígenas que chegaram à Terra, o físico Gary Donnelly e a linguista Louise Banks. Havia doze aparelhos extraterrestres nos EUA e cento e doze no mundo. O Coronel apresenta a Louise uma gravação que eles haviam realizado com sons emitidos pelos alienígenas, mas a gravação "soava vagamente, como um cachorro molhado sacudindo a água do pelo" (CHIANG, 20165). A ideia do exército era de que Louise fizesse a tradução da mensagem gravada sem manter contato com os seres alienígenas, contudo ela constata que o trato vocal daqueles seres era radicalmente diverso do humano e afirma que só seria possível caso tivesse contato efetivo com eles. Em função disso, ela é enviada para um dos espelhos/aparelhos alienígenas em companhia do já citado físico, entretanto, ao longo de todo o conto, é ela, com sua ciência linguística, e não Gary Donnelly, que protagonizará o contato, o qual é o nó fundamental que rege toda a trama narrativa. Logo, é a Linguística e a Hermenêutica, e não a Física, o centro narrativo de uma ficção científica, chamando a

5 Como se trata de uma versão de e-book Kindle, as páginas não serão citadas. 
atenção para a perspectiva heideggeriana de tecnologia, conforme Adam Roberts, que representaria um ponto de vista sobre o mundo, um modo de ver o homem e as coisas que o rodeiam. Articulamos a Hermenêutica relacionada à Linguística, porque, no caso do conto, Louise tem que lidar não apenas com a decifração de uma linguagem estranha, mas dar sentido a ela, interpretando-a. Gary, o físico, acaba por atuar de forma secundária no enredo; pode-se até dizer que sua principal função, além de ser confidente da linguista Louise, é conceber juntamente com ela uma filha.

Convencionalmente entende-se a narrativa de ficção científica como aquela que tem em sua base uma questão relacionada à ciência. Gernsback (Apud CAUSO, 2003, p.52) define a "scientifiction" como "um encantador romance entremeado de fato científico e visão profética". Muitos dos estudiosos da ficção científica, seguindo a linha de Gernsback, caracterizam-na como uma espécie de literatura em que a ciência deve fazer-se presente, gerando no leitor quase sempre uma expectativa de que essa ciência deve relacionar-se à área de exatas ou quando muito à de biológicas, porém raramente se cogita a vinculação de ciência à área de humanas. Conforme Adam Roberts (2018) elucida, alguns críticos literários, ao definirem a ficção científica, fazem-no considerando sua relação de afinidade com a literatura fantástica: "a diferença se encontra em um discurso materialista, científico, quer a ciência evocada esteja ou não em acordo com a ciência que conhecemos hoje" (ROBERTS, 2018, p.39). Por essa acepção, já se percebe que o sentido de ciência esgarça-se um pouco e amplia seu campo de atuação. Adiante, na conclusão do primeiro capítulo do seu livro A verdadeira história da ficção científica, 
Adam Roberts (2018, p.60) defende que a "FC é mais bem definida como ficção tecnológica, desde que não encaremos tecnologia como sinônimo de engenhocas, mas, em sentido heideggeriano, como um modo de enquadrar o mundo, manifestação de uma perspectiva fundamentalmente filosófica". Enfatizamos esse aspecto porque pode causar estranhamento no conto de Chiang: a ciência posta em relevo ser a Linguística, da Humanas.

O conto insere-se na coletânea de contos intitulada História da sua vida e outros contos (2016), de autoria do autor estadunidense Ted Chiang, já agraciado com os Prêmios Nebula, Hugo e Locus por sua produção no campo da ficção científica. O conto "História da sua vida" teve sua adaptação para o cinema com o filme intitulado A chegada (2016), dirigido por Denis Villeneuve. Nesta parte do presente ensaio, jogaremos luz especialmente sobre como são configurados esses seres maravilhosos, os alienígenas, na diegese criada por Chiang, bem como da relação que tais alienígenas estabelecem com os humanos, por meio de um elemento tão importante para entender as diferenças entre seres e entre mundos: a linguagem - esta, que, no conto, é o principal presente que os alienígenas nos oferecem.

No conto de Chiang, a narrativa possui dois movimentos discursivos diferenciados que se completam, se superpõem, se embaralham e dialogam, seja de forma sutil ou desvelada: um movimento conta a história do contato da linguista, Dra. Louise Banks, convocada pelos militares dos Estados Unidos da América para traduzir a linguagem dos alienígenas que chegaram ao planeta Terra; o outro movimento revela-se como uma espécie de carta que Louise escreve para sua filha, uma carta em que 
a linguista revelará que possui a visão da morte da menina. Desconstruindo uma lógica narrativa tradicional, o conto não se inicia com a narrativa do contato, mas com a narrativa da visão. A desconstrução ocorre na medida em que se espera que inicialmente se fale primeiro do acontecimento inicial (o contato) que possibilitou o outro acontecimento posterior (visão do futuro); entretanto a inversão é repleta de sentido, uma vez que essa visão do futuro é possibilitada pelo contato de Louise Banks, a linguista, com a linguagem dos alienígenas, a qual é caracterizada por desenhos semagráficos que articulam "ideias complexas, todas ao mesmo tempo" (CHIANG, 2016), em todas as direções. Nesse sentido, não há uma linearidade sintática que subordina tudo à ordem, por exemplo, de passado-presente-futuro, e então o futuro pode vir naturalmente anteposto ao passado.

Alguns podem porventura questionar se essa narrativa seria um drama ou uma ficção científica, já que há a morte da filha como um dos motivos da narrativa. Há dois problemas que estão na base dessa indagação: o primeiro relativo ao gênero e o segundo ao estatuto estético. Em relação ao segundo ressaltamos que há ainda hoje um enorme preconceito em torno da produção e da recepção da ficção científica em função de ela ser vinculada frequentemente à literatura de massa e, nessa linha de entendimento, é muitas vezes e erroneamente caracterizada como uma literatura de menor qualidade estética; entretanto, esse preconceito trata-se de fato de um pré-conceito ipsis litteris, como defendemos ao longo deste ensaio, ou seja, de um julgamento anterior mesmo à experiência, uma vez que não se pode julgar uma literatura sem, antes de tudo, lê-la, sem experimentar o prazer estético inerente à leitura que se 
faz dela. Todavia, isso vale não só para uma literatura considerada, de antemão, trivial, como a novela de detetives ou a ficção científica; tal postura deve ser válida também para textos que geralmente são considerados como alta literatura. Muitas vezes, por exemplo, falta poesia em livros de poesia ou falta dramaticidade em textos dramáticos. Na área de produção relacionada à ficção científica, por exemplo, vimos que a obra de H.G. Wells tem uma indiscutível qualidade literária.

É, portanto, a leitura do discurso inscrito em uma narrativa de ficção científica que nos permite apreciar se ela possui ou não qualidade literária, e não simplesmente a sua inserção em um gênero vinculado usualmente à literatura trivial. No caso de "História de sua vida", o discurso ficcional foge radicalmente da fórmula que compõe a narrativa trivial, como a linearidade sequencial ou a veiculação de significados simplistas; pelo contrário, sua tessitura discursiva e ficcional ergue-se de modo a tornar complexa a construção do enredo, das personagens, do jogo entre temporalidades e espacialidades, da condução retórica do narrador, enfim, possibilitando a deflagração de sentidos múltiplos e polissêmicos.

Quanto ao aspecto relativo ao gênero, deve-se considerar que, mesmo após tantas revoluções na história da arte que evidenciaram o hibridismo, em geral há ainda uma insistência em dividir, categorizando e separando em espaços distintos, textos que devam pertencer a esse gênero e não àquele; contudo os textos, e especialmente os literários, muitas vezes fazem uso do hibridismo para gerar potenciais efeitos de sentido, como ocorre em "História da sua vida", que é uma narrativa que conjuga muito habilmente 
elementos dramáticos e de ficção científica; logo, não há motivo para evidenciar um gênero em detrimento do outro.

Uma das categorizações mais recorrentes no âmbito da ficção científica é a de ficção científica hard e soft, elucidada por Roberto Belli (2012, p.94-5). A primeira compõe-se de narrativas cujo núcleo do enredo é a própria ciência; já a ficção científica soft coloca no cerne do enredo os relacionamentos entre as personagens e as questões de ordem muito mais social do que científica. Particularmente, não somos adeptas às delimitações redutoras, entretanto, de posse dessa informação, podemos deduzir que o conto de Chiang aproxima-se muito mais de uma ficção soft, porque, ainda que tenha toda uma exploração de recursos e elementos da ciência linguística, é a humanização do alienígena e principalmente a humanização do humano (Louise), que está no centro da trama.

Devemos ressaltar que o drama desvelado não seria possível ser configurado da forma tão ímpar como aparece no conto sem os elementos da ficção científica. Não se trata de uma relação qualquer, mas de uma humana que, tratando o alienígena como sujeito e não como mero objeto, recebe dele um presente: a sua linguagem, uma linguagem que dará a ela e aos demais homens terem ciência de seu presente, de seu passado e de seu futuro. A riqueza do desvendamento de uma linguagem capaz de ler o futuro, presente ofertado por um extraterrestre é que desencadeará na trama o drama de Louise, pois, mesmo sabendo que terá uma filha e que esta morrerá ainda adolescente, ela decide, ainda com tanta dor (a dor de uma perda antecipada), ter a filha e contar a ela a história de sua vida. 
A posse da linguagem alienígena por Louise acontece de forma gradativa. Em seu contato humanizador, Louise começa a estudar não somente a língua falada, como também a escrita deles e vai se apropriando de um modo completamente diferente do nosso de grafar a escrita. A princípio Louise percebe que não era uma escrita alfabética e supõe que fosse ideográfica, porém, logo depois de algumas experimentações, ela percebe que era uma escrita feita por meio de logogramas, cuja configuração não era estática, mas se movimentava. Como os corpos dos heptápodes ${ }^{6}$, que não tinham direção definida, nem definitivamente trás, nem definitivamente frente, a escrita deles era lida em várias direções possíveis e em função dessa natureza pluridirecional e pluriespacial essa linguagem era também pluritemporal, açambarcando o que já havia acontecido e o que ainda estava no porvir. Após deixarem esse legado, o legado de sua linguagem, aos humanos terrestres, os alienígenas evadem da Terra. A maioria das pessoas não entende a evasão tão repentina, mas Louise recebe o presente como uma nova posse. Apesar de amarga a posse, é ela que fará Louise conquistar um novo olhar sobre o mundo e rever os limites de sua humanidade e dos outros: "em comparação aos espelhos dos heptápodes, assim meus colegas pareciam mais distantes que os alienígenas. O familiar estava longe, enquanto o bizarro estava ao alcance das mãos" (CHIANG, 2016). Léo Godoy Otero (1987, p.14), ao fazer uma leitura das ideias do autor Theodore Sturgeon, afirma que ficção científica em geral tem sua qualidade mais elevada quando a narrativa é desenvolvida em torno da problematização da condição humana, como vemos irromper no conto de Chiang. 
Lembremo-nos de que Gernsback (Apud CAUSO, 2003) define a ficção científica por meio de duas presenças: a do fato científico propriamente dito e a da visão profética. Parece-nos que Chiang contempla muito bem ambas as presenças e faz de seu conto um exemplo rico de ficção científica. A predição do futuro seria um elemento que faria parte da fenomenologia do metaempírico, já que, em nosso atual mundo empírico, tal predição situa-se no plano da impossibilidade lógica. Observemos que o metaempírico não tem existência no ambiente de recepção atual da leitura que aqui se faz do conto, mas não inviabiliza que essa existência situe-se em um porvir próximo ou distante.

Em nosso entendimento, o novum, nessas narrativas de alienígenas, como as que focalizamos neste ensaio, são os próprios alienígenas, como dito anteriormente, na medida em que eles nos apresentam novas e inusitadas formas de experiências, mentalidades e possibilidade de olhar o mesmo - o nosso mundo -, porque, como afirma Patrick Parrinder (Apud ROBERTS, 2018, p.37), "ao imaginar mundos estranhos [ou seres estranhos, acrescentamos], acabamos vendo nossas próprias condições de vida em uma perspectiva nova e potencialmente revolucionária".

O contato com esse novum, o alienígena, é estarrecedor no conto, Louise dá um pulo quando o primeiro deles entra em seu campo de visão pela grande diferença corporal que apresenta:

Parecia um barril suspenso no ponto em que seus sete membros se encontravam. Era radialmente simétrico, e qualquer um dos membros podia servir como braço ou perna. O que estava à minha frente caminhava em quatro pernas, com três braços não adjacentes curvados junto à lateral do corpo. Gary os chamou de "heptápodes". (CHIANG, 2016) 
Além disso, os membros deles não aparentavam juntas visíveis, era uma anatomia completamente diferente da humana, "com olhos em todos os lados, qualquer direção seria a da frente" (CHIANG, 2016). Apesar da grande diferença do alienígena e de esta ter provocado na linguista um susto enorme, o contato segue de forma tranquila, humanizada e humanizadora, pois Louise tenta travar um diálogo em que as afinidades, e não as diferenças, sejam ressaltadas, por isso ela também faz questão de nomeá-los com apelidos carinhosos - Melindrosa e Framboesa. Assim, o modo como eles são "demonstrados" no início pode causar estranhamento, porém, depois, com todo o contato diário de Louise com eles, ao leitor é desvelada uma face menos horrífica do ser extraterrestre, a despeito de todas as brutais diferenças que apresentam em relação à "normalidade" humana. Utilizamos o vocábulo "demonstrados" e não "representados", como seria mais usual, porque entendemos, com Roland Barthes (2007, p.21), que o real não é "representável, mas somente demonstrável". Mesmo sendo uma "realidade" da ordem do metaempírico, é uma realidade que pretende um diálogo com mundos possíveis - o nosso e o dos alienígenas.

Nas histórias de ficção científica, aparecem frequentemente dois tipos de alienígenas, como estamos defendendo desde o início deste ensaio: "aqueles que chegam a nós como 'invasores hostis' e aqueles que chegam como 'modelos de comportamento'" (SLUSSER; RABKIN Apud GINWAY, 2010, p.53). Para M. Elizabeth Ginway (2005, p.20), os "alienígenas servem muitas vezes como os alter egos da humanidade, como representações do admirado e/ou temido". Eles são, em geral, imagens alteradas de nossa humanidade. Via de regra, como esclarece Filipe Furtado (2017, p.137), eles são retratados como 
"coisas", porque são da ordem do indizível e do inenarrável. Como demonstramos, no primeiro momento do conto de Chiang, parece que a narrativa vai seguir a linha de demonstração do alienígena como o monstro a ser temido, todavia, logo depois essa face do mal, que é configurada pela diferença (o mal e o feio são sempre o diferente de nós), dissipa-se e vemos o trabalho de Chiang com alienígenas que são apresentados como doadores de um bem.

É interessante como a narrativa de Chiang escapa do que se espera normalmente, pois, os alienígenas, mesmo apresentando uma forma totalmente distinta e monstruosa, não são hostis e não oferecem perigo. Nós, leitores, somos surpreendidos por esses extraterrestres e os humanos de sua história, em sua grande maioria, parecem não aceitar que eles chegaram sem intenções maldosas. Como dissemos, Wells criou um sustentáculo para o que as histórias de invasões alienígenas viriam a ser e o seu modelo tem sido reproduzido constantemente desde então. Acostumamo-nos com os perigosos extraterrestres e nos esquecemos daqueles possíveis sábios seres extraterrenos, como o gigante de Voltaire, Micrômegas.

Voltaire, filósofo iluminista do século XVI, escreveu Micrômegas no ano de 1752 e, como em toda sua obra, nesse conto filosófico explora algumas de suas principais defesas, como a das liberdades civis e sua oposição às rígidas imposições religiosas. Micrômegas é um ser extraterrestre gigantesco que vive no planeta Sirius e contém um grande conhecimento acerca das questões do universo; por isso decide viajar até o sistema solar para conhecer seus habitantes e discutir com eles seus conhecimentos. Em Saturno, encontra um povo dotado de muita inteligência, mas ainda menor do que a sua e leva consigo um companheiro para explorar os demais planetas. 
Em Marte, não encontra nenhum tipo de vida e em um salto chega à Terra, que inicialmente também lhe parece desabitada. Depois de um olhar mais atento, que só é possível por meio de um diamante que funciona como uma lupa, Micrômegas percebe que pequeníssimos seres vivem na Terra e conversa com eles. As discussões de Micrômegas sempre buscam investigar o que esses pequenos habitantes do planeta Terra conhecem e o extraterrestre se surpreende com o quanto o conhecimento de física, geometria e matemática são avançados em nosso planeta. Contudo, quando pergunta sobre questões existenciais como, de onde aqueles seres vieram, para onde irão, porque existem, cada um dos filósofos com quem ele conversava responde de uma forma. $\mathrm{O}$ gigante percebe que não há um consenso nesses temas e promete aos humanos que Ihes enviará um presente contendo todas essas respostas.

Micrômegas, assim como os alienígenas de "História de sua vida", presenteia os humanos com um conhecimento. Contudo o presente desse gigante é bem diferente daqueles outros, trata-se de um livro em branco, uma grande ironia acerca das certezas. O sábio Micrômegas sabe que muitas vezes é impossível se chegar a respostas absolutas, especialmente quando se tratam de questões existenciais.

Voltaire, que era grande fã de Newton, buscava em sua escrita ironizar e abandonar os fundamentos teocêntricos para dar lugar ao pensamento racional e científico. Sua obra apresenta um alienígena que é fundamental para a problematização iluminista, mas que, principalmente, antecipa uma literatura que terá maior expressividade no século XIX, com Wells, e sua relevância se reflete ainda hoje, como podemos perceber na forte influência no conto de Ted Chiang. 
Percebemos que o extraterrestre não é demonstrado de forma una, no cinema e, especialmente, na literatura. Eles podem nos presentear ou tentar nos destruir, podem até mesmo precisar de nossa ajuda e serem nossos amigos. Buscamos mostrar neste ensaio que apesar de o E.T. ocupar várias vezes um lugar marginal, assim como aquele da ficção científica, corresponde a um importante ser maravilhoso ao longo dos séculos e que sempre disse muito sobre os homens e sua humanidade ou desumanidade. O alienígena, que tem seu auge no século $X X$, mas que sempre esteve presente na imaginação de escritores, é uma presença indispensável e insubstituível nos textos em que aparece. A Guerra dos mundos não seria a mesma e não causaria tanto impacto até hoje se fosse apenas uma guerra de países, Micrômegas não seria tão relevante para o pensamento racionalista se fosse somente a representação de um Deus, Uma história verídica de Luciano seria apenas mais uma obra tentando reproduzir o sucesso de $A$ Odisseia se suas personagens se encontrassem com seres míticos ou invés de extraterrestres e "A história de sua vida" pareceria uma história do século passado se não tivéssemos o presente alienígena, mas sim uma bola de cristal. Nesse sentido, em todas essas obras, destacamos que o uso de elementos da ficção científica na composição das suas tramas revela-se como um potencial e frutuoso recurso estético.

\section{REFERÊNCIAS}

BARTHES, Roland (2007). Aula. São Paulo: Cultrix.

BELLI, Roberto C. (2012). Fiç̧ão científica: um gênero para a ciência. Blumenau: Edifurb.

BURLESON, Donald R. (2007). The Alien. In: JOSHI, J. T. (Org.). Icons of horror and the supernatural: an encyclopedia of our worst nightmares. London: Greenwood Press. 
CARPENTIER, Alejo (1987). A literatura do maravilhoso. São Paulo: Vértice.

CAUSO, Roberto de Sousa (2003). Ficção científica, fantasia e horror no Brasil: de 1875 a 1950. Belo Horizonte: Editora da UFMG.

CHIANG, Ted (2016). A história da sua vida e outros contos. Rio de Janeiro: Intrínseca. [e-book em kindle].

FURTADO, Filipe (2018). "Fantástico Modo". In: E-Dicionário de Termos Literários (EDTL). CEIA, Carlos (Coord.). In http://www.edtl.com.pt. Acesso em Nov.2018. (2017). O fantástico: procedimentos de construção narrativa em H. P. Lovecraft. Rio de Janeiro: Dialogarts Publicações.

GINWAY, M. Elizabeth (2005). Ficção cientifica brasileira: mitos culturais e nacionalidade no país do futuro. Roberto de Sousa Causo (Trad.). São Paulo: Devir. GINWAY, M. Elizabeth (2010). Visão alienígena: ensaio sobre a ficção científica brasileira. São Paulo: Devis.

LUCIANO (s/d). Uma história verídica. Lisboa: Editorial Inquérito.

OTERO, Léo Godoy (1987). Introdução a uma história da ficção científica. São Paulo: Lua Nova.

ROBERTS, Adam (2018). A verdadeira história da ficção cientifica-do preconceito à conquista das massas. São Paulo: Seoman.

VOLTAIRE (2007). Micrômegas e outros contos. São Paulo: Hedra.

WELLS, H.G. (2016). A guerra dos mundos. Rio de Janeiro: Suma de Letras. 